ISSN (Print) : 1412-7601

ISSN (Online) : 2654-8712

Volume 7, No.2 September 2021

EKONOBIS

http://www.ekonobis.unram.ac.id

\title{
Komparatif Government Size Provinsi Nusa Tenggara Barat (NTB) dan Nusa Tenggara Timur (NTT)
}

\section{Siti Sriningsih.}

Universitas Mataram

\begin{tabular}{l|l}
\hline A R T I C L E I N F O & $\begin{array}{l}\text { ABSTRACT : The ratio of local taxes to PAD and ABD is a goal that will be analyzed } \\
\text { Survey, formal worker, } \\
\text { informal workers, } \\
\text { Mataram City } \\
\text { taxes in the District/City of the Province of NTB range from 5-10\% of the PAD, but } \\
\text { there are also districts that are still low with a contribution of below 5\%, } \\
\text { especially for districts/cities that have just been divided. The same applies to } \\
\text { regencies/cities in NTT Province, where the ratio of tax to PAD ranges from 1-5\%. } \\
\text { The difference between the two provinces is caused by the variation in the types } \\
\text { of taxes collected in each region. In NTB the types of taxes collected are 8-11 } \\
\text { types, while in NTT 6-10 types. The potentials in the two regions are also different } \\
\text { wherein NTB there are more types of taxes in the fields of tourism and services } \\
\text { and business, while in NTT they rely more on natural resources in the field of non- } \\
\text { metallic minerals and rocks and class C excavation. }\end{array}$ \\
\hline $\begin{array}{l}\text { Kata Kunci: } \\
\text { Pajak daerah, , PAD, } \\
\text { Kontribusi pajak } \\
\text { dianalisis dengan menggunakan metode rasio PAD dan APBD. Adapun hasilnya adalah } \\
\text { dana yang bersumber dari pajak di Kabupaten/Kota Privinsi NTB berkisar antara 5- } \\
\text { 10\% dari terhadap PAD, tapi ada juga kabupaten yang masih rendah dengan } \\
\text { kontribusi di bawah 5\% terutama bagi daerah kabupaten/kota yang baru terjadi } \\
\text { pemekaran. Begitu pula dengan Kabupaten/Kota di Provinsi NTT yang rasio pajak } \\
\text { terhadap PAD berkisar antara 1-5\%. Perbedaan dari kedua provinsi disebabkan oleh } \\
\text { pariasi jenis pajak yang dipungut di setiap daerah. Di NTB jenis pajak yang dipungut } \\
\text { adalah 8-11 jenis, sedangkan di NTT 6-10 jenis. Potensi di kedua daerah juga berbeda } \\
\text { dimana di NTB lebih banyak jenis pajak di bidang pariwisata dan jasa serta bisnis, } \\
\text { sedangkan di NTT lebih mengandalakan sumber daya alam di bidang mineral bukan } \\
\text { logam dan batuan serta galian golongan C. }\end{array}$ \\
\hline
\end{tabular}

Corresponding Author:

Alamat : Program Studi Ekonomi Pembangunan, Fakultas Ekonomi dan Bisnis, Universitas Mataram, Jln. Majapahit No. 62 Mataram.

e-mail: siti.sriningsih1206@gmail.com 


\section{PENDAHULUAN}

\section{Latar Belakang}

Tujuan Pembangunan Nasional yaitu mewujudkan kesejahteraan masyarakat, terwujudnya kesejahteraan akan terkait dengan anggaran yang dimiliki setiap daerah. Isu mengenai ketergantungan fiskal dalam desentralisasi fiskal tetap menjadi perhatian untuk dikaji, seperti sekarang ini usia implementasi otonomi daerah dan desentralisasi fiskal pada akhir tahun 2020 adalah 20 tahun. Otonomi daerah dan desentralisasi fiskal di Indonesia diatur dengan Undang-Undang Nomor 2 Tahun 2015 tentang Perubahan Kedua Atas Undang-Undang Nomor 23 Tahun 2014 Tentang Pemerintahan Daerah, serta UU No. 33 Tahun 2004 tentang Perimbangan Keuangan Antara Pemerintah Pusat dan Pemerintah Daerah. Bentuk upaya yang dilakukan pemerintah dalam penguatan desentralisasi fiskal pada tahun 2019 adalah dalam RAPBN alokasi dana transfer meningkat menjadi $9 \%$ dari perkiraan realsasi tahun 2020. Diharapkan dana transfer yang direncanakan tersebut untuk secara mandiri menjalankan kewenangan yang dilimpahkan kesemua bidang. Namun isu yang berkembang dimana ketergantungan daerah terhadap dana transfer dari pemerintah pusat masih sangat tinggi yaitu secara rata rata nasional ketergantungan APBD terhadap dana transfer sebesar $80 \%$ sementara kontribusi PAD sekitar 12,87\%. Keterbatasan anggaran menjadi isu klasik yang menyebabkan perlunya manajemen anggaran yang tepat.

Optimisme desentralisasi semakin surut setelah berjalan lebih dari sepuluh tahun. Semakin panjang umur desentralisasi daerah, semakin menumpuk persoalan klasik yang tak pernah kunjung terselesaikan dan berulang kembali selama bertahun-tahun Oleh karena heterogenitas daerah di Indonesia sangat besar, maka banyak daerah yang justru tidak memiliki kemampuan fiskal yang memadai (Adhamaski, 2015). Mewujudkan pelayanan publik yang baik kepada masyarakat akan terkait dengan APBD yang dialokasikan kesetiap Kabupaten/Kota diseluruh Indonesia. Alokasi belanja terkait dengan program/kegiatan dan sumber-sumber pendapatan yang akan digunakan untuk mendanai kebutuhan daerah.

Pendapatan Pemerintah Daerah (pemda) dan sebagian besar terdiri dari transfer antar pemerintah (dana perimbangan) dan pendapatan asli daerah (PAD). Pemerintah daerah memiliki pendapatan dari sumber mereka sendiri dari pajak lokal, bea lokal, pendapatan dari aset daerah dan pendapatan lainnya. Jika perlu, mereka bisa juga menerbitkan obligasi. Komponen pajak lokal untuk pemerintah provinsi dan kabupaten/kota berbeda; pemerintah provinsi berwenang mengumpulkan pajak lokal yang menguntungkan, seperti pajak bahan bakar, pajak registrasi kendaraan, pajak transfer kepemilikan kendaraan, dan pajak air tanah. Sebaliknya, pemerintah kabupaten/kota hanya bisa mengenakan tujuh macam pajak lokal yang tidak menguntungkan: pajak hotel, pajak restoran, pajak hiburan, pajak iklan, pajak penerangan jalan, pajak parkir dan pajak galian sirtu (pasir dan batu), (Word Bank, 2011).

Tabel berikut menunjukkan realisasi pendapatan dari provinsi Nusa Tenggara 
Barat (NTB) di seluruh Kabupaten/Kota selama sepuluh tahun, dimana terlihat dari tahun 2010 - 2020 mengalami peningkatan. Tentunya pendapatan yang diperoleh adalah bersumber dari PAD dan dana perimbangan. Pada Grafik menunjukkan bahwa realisasi dari penerimaan daerah meningkat dari 1 - 5\%.

\section{Grafik 1. Pendapatan pemerintah daerah tahun 2010 -2020 di NTB}

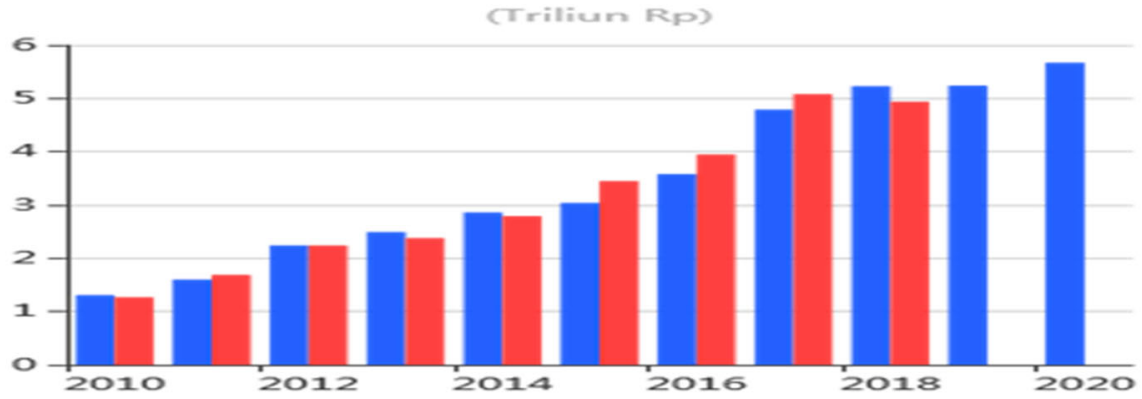

Sumber: djpk.kemenkeu.go.id

Grafik 2. Pendapatan daerah tahun $\mathbf{2 0 1 0 - 2 0 2 0}$ di NTT

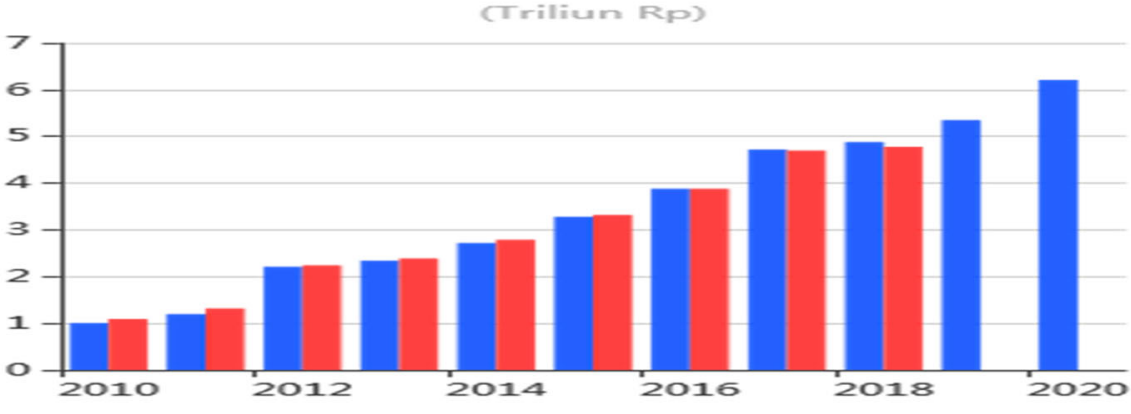

\section{Sumber: djpk.kemenkeu.go.id}

Terlihat pada grafik 2 di provinsi NTT realisasi untuk pendapatan daerah juga berkisar dari 1-5\%. Jika melihat pendapatan di dua provinsi dimana NTB dan NTB yang memiliki potensi daerah yang berbeda namun realisasi pendapatan daerah masih dibawah 5\%. Tentunya kondisi ini akan mengarah pada berbagai program yang akan di anggarkan dalam pemenuhan layanan publik.

Paper ini menguraikan tentang government size (rasio pajak daerah terhadap PAD dan APBD) dengan membandingkan dua provinsi yaitu provinsi NTB dengan NTT. Tentunya analisis terkait dengan kinerja keuangan
APBD dilakukan dengan melihat beberapa hal yaitu rasio pajak (tax ratio), ruang fiskal (fiscal space), serta rasio kemandirian daerah. Rasio pajak mencerminkan hubungan pajak daerah dengan pendapatan domestic regional bruto (PDRB). Daerah yang menunjukkan rasio pajak yang tinggi adalah di wilayah JawaBali, Berbagai kemungkinan bisa terjadi yang disebabkan oleh tingginya penerimaan pajak daerah, rendahnya PDRB, atau potensi pajak daerah di Jawa dan Bali yang memang tinggi (Kementrian Keuangan, 2011). Peper ini hanya berfokus pada rasio pajak daerah. 
REVIEW LITERATUR

Kemampuan keuangan Pemerintah Kabupaten-Kota di Jawa Barat mayoritas masih tergolong "KURANG", dimana sejumlah 17 (tujuh belas) Kabupaten-Kota atau $62,96 \%$ memiliki Rasio Desentralisasi Fiskal di bawah $20 \%$. Komponen PAD yang menyumbang porsi besar pada realisasi PAD bersumber dari Pajak Daerah, berupa hasil pungutan BPHTB, PBB, Pajak Restoran, dan Pajak Hotel, yang menunjukkan aktivitas ekonomi di masyarakat mulai berkembang (Zulkarnain,2020). Begitu pula dengan studi mengenai Rasio PAD/Total Pendapatan Daerah untuk melihat kemandirian secara rata-rata hasil perhitungan rasio kemandirian daerah kabupaten/kota di Aceh sebesar 4,75 persen dan di SumateraUtara sebesar 6,06 persen (Suryani dkk, 2016).

\section{METODOLOGI}

Metode yang digunakan dalam perhitungan Goverment Size (rasio pajak daerah terhadap PAD dan APBD), (Abdul, 2001):

$$
\frac{x}{y} x 100 \%, \text { dan } \frac{z}{y} x 100 \%
$$

$\mathrm{X}=$ Realisasi penerimaan pajak daerah

$\mathrm{Y}=$ Realisasi penerimaan $\mathrm{PAD}$

$Z=$ Realisasi penerimaan APBD

Dengan analisis ini kita akan mendapatkan seberapa besar kontribusi pajak daerah dan retribusi daerah terhadap pendapatan asli daerah (PAD) dan APBD. Dengan membandingkan hasil analisis tersebut dari tahun ke tahun akan mendapatkan hasil analisis yang berfluktuasi dari kontribusi tersebut dan akan diketahui kontribusi yang terbesar dan yang terkecil dari tahun ke tahun.

HASIL DAN PEMBAHASAN

Target dan realisasi PAD di NTB

Grafik.3. Target dan realisasi PAD Nusa Tenggara Barat (NTB) tahun 2008-2019

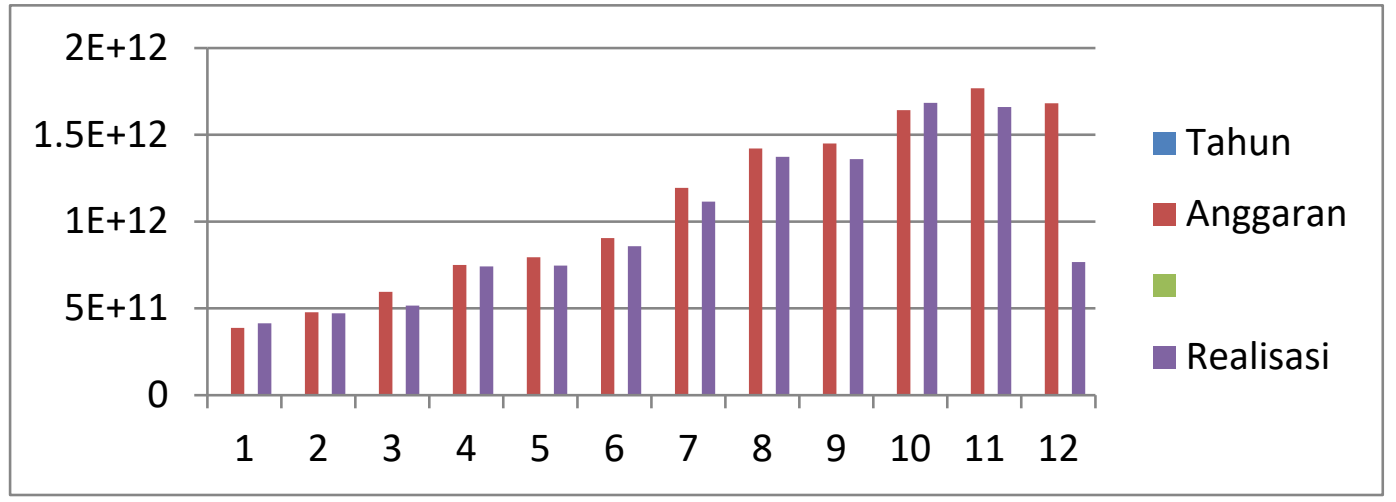

\section{Sumber: NTB dalam angka diolah}

Grafik 3 memberikan gambaran terkait dengan realisasi anggaran dan target PAD di NTB di semua Kabupaten/Kota, yang dimana terlihat masih berfluktuasi, pada tahun 2008 realisasi $100 \%$ dari yang ditargetkan begitu pula pada tahun 2017 juga diatas $100 \%$. Namun pada tahuntahun yang lain mengalami penurunan atau dibawah target dalam mendapatkan pertambahan PAD Kabupaten/Kota di NTB. 


\section{Target dan realisasi PAD di NTT}

Grafik 4. Target dan realisasi PAD di Provinsi NTT tahun 2014-2018

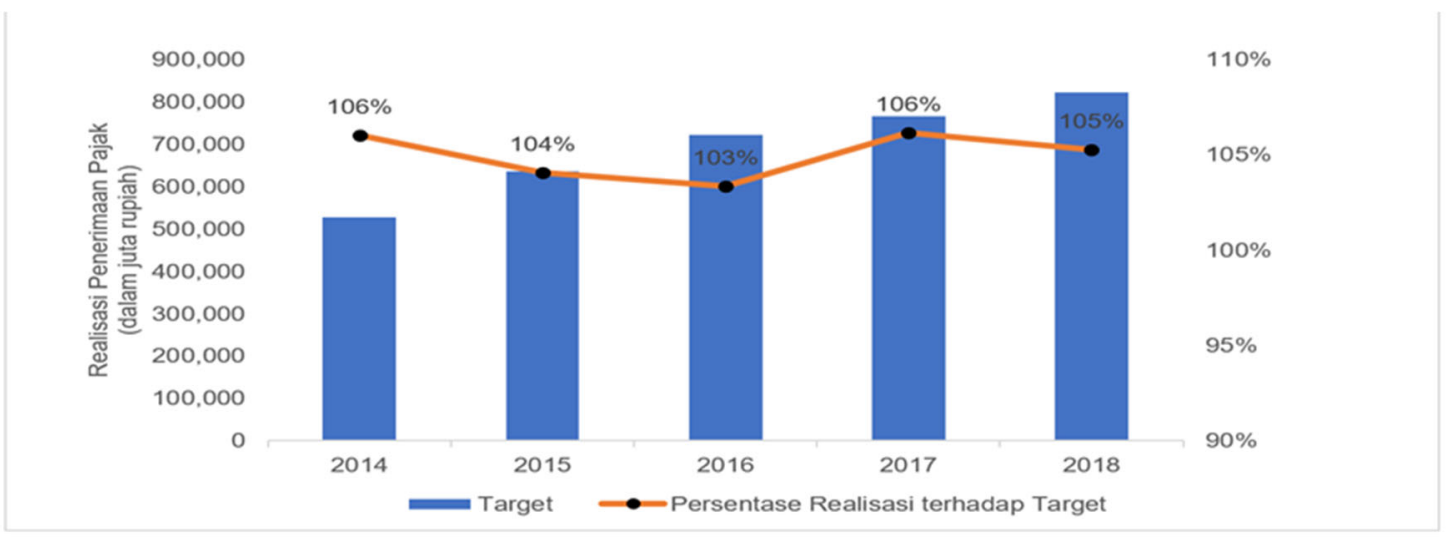

\section{Sumber: ddtc.co.id}

Grafik 4 menunjukkan target dan realisasi PAD pada provinsi NTT, realisasi dari tahun 2014 diatas 100\%, yang berarti realisasi ini melebihi target. Perbedaan yang terjadi pada tingkat realisasi di NTB dan NTT terletak pada sumber pendapatan daerah masing-masing. Sumber pendapatan asli daerah disetiap wilayah pada tingkat kabupaten/kota berbeda.

\section{Jenis pajak setiap Kabuapten/Kota di} Masing-masing Provinsi

Pajak yang dipungut pemerintah tidak hanya pajak pusat, tetapi ada pajak provinsi dan pajak kabupaten/kota. Apabila melihat pengelompokan pajak berdasarkan pengelolaannya, pajak dibagi menjadi pajak pusat dan pajak daerah, dan pajak daerah itu sendiri terdiri dari pajak provinsi dan pajak kabupaten/kota. Pajak Pusat adalah pajak-pajak yang dikelola oleh Pemerintah Pusat yang dalam hal ini sebagian dikelola oleh Direktorat Jenderal Pajak - Departemen Keuangan. Sedangkan Pajak Daerah adalah pajak-pajak yang dikelola oleh Pemerintah Daerah baik di tingkat Propinsi maupun Kabupaten/Kota. Menurut Ismail (2007): "Pajak daerah pada dasarnya merupakan sumber penerimaan daerah yang paling utama dalam membiayai semua keperluan pelaksanaan tugas, fungsi, dan kewajiban pelayanan pemerintah daerah kepada rakyatnya". Menurut Undang-Undang No. 28 Tahun 2009 bahwa pajak daerah dan retribusi daerah (UU PDRD) merupakan salah satu sumber pendapatan daerah yang penting guna membiayai pelaksanaan pemerintahan daerah. Adapun jenis sumber pendapatan pajak kabupaten/Kota pada Gambar 1. 
Gambar 1. Jenis Pajak Kabupaten/Kota berdasarkan UU No. 28 Tahun 2009

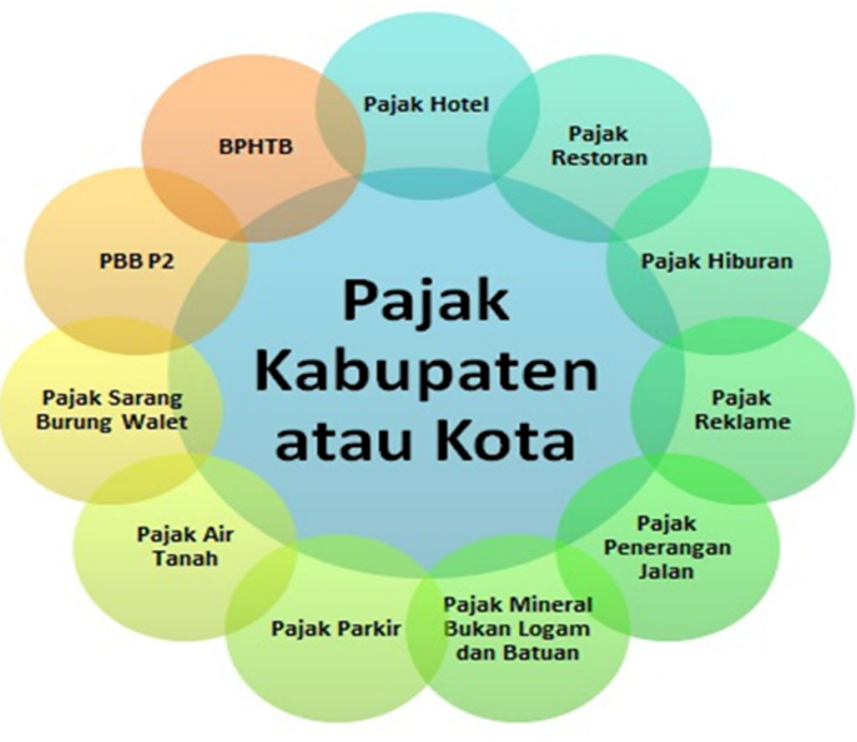

\section{Provinsi NTB}

Kabupaten Bima memiliki beberapa jenis pajak yang menjadi sumber pajak adalah: pajak hotel, pajak restoran, pajak reklame, pajak penerangan jalan, pajak air tanah, pajak mineral bukan logam, PBB pedesan dan kota, Perolehan Hak atas Tanah dan Bangunan (BPHTB). Sehingga jika dilihat di Kabupaten Bima memiliki 8 jenis pajak yang menjadi sumber pendapatan asli daerahnya. Yang paling besar memberikan kontribusi adalah pajak penerangan jalan $6 \%$, diikiuti oleh pajak PBB kota dan Desa $16 \%$, dan pajak logam dan mulai sebesar $17 \%$, sedangkan untuk pajak lain perkisaran 17\%, dan BPHTB sebesar 0,06\%, sisanya adalah dari sumber jenis pajak yang lain.

Kabupaten Dompu juga memiliki 8 jenis pajak yang menjadi sumber PAD sperti pada Kabupaten Bima. Kontribusi yang terbesar diberikan oleh pajak penerangan jalan sebesar $50 \%$, BPHTB, dan pajak hotel dan restoran sebesar $2 \%$ memberikan kontribusinya.
Kabupaten Lombok barat memiliki 10 jenis pajak yang memberikan kontribusi ke PAD. Berbeda dengan Kabupaten Bima dan Dompu yang memiliki 8 jenis sedangkan di Lombok Barat 2 jenis pajak seperti Pajak Air tanah dan PBB memberikan tambahan pada jenis pajak. Pajak Hotel dan restoran memberikan kontribusi yang terbesar 33\%, BPHTB sebesar 16\%, PBB sebesar $10 \%$, Pajak penerangan jalan $18 \%$, dan sisanya tersebar pada jenis pajak lain yang memberikan kontribusi pada PAD.

Kabupaten Lombok tengah memiliki 11 jenis pajak yangmemberikan kontribusi terhadap PAD. Seperti pada Kabupaten Lombok Barat yang memiliki 10 jenis pajak tetapi di Kabupaten Lombok tengah ditambah dengan pajak sarang burung walet sehingga menjadi 11 jenis pajak. BPHTB memiliki kontribusi sebesar 25\%, PBB pedesaan dan kota sebesar 23\%, Pajak penerangan jalan sebesar 22\%, Pajak restoran $8 \%$, pajak hotel sebesar $7 \%$, dan sisanya terbagi ke jenis pajak yang lainya. 
Kabupaten Lombok timur memiliki 11 jenis pajak yang memberikan kontribusi terhadap PAD seperti yang dimiliki oleh Kabupaten Lombok tengah. Kontribusi terbesar diberikan dari pajak penerangan jalan sebesar 35\%, PBB pedesaan dan Kota $15 \%$, Pajak mineral bukan batuan logam sebesar $27 \%$, BPHTB sebesar $10 \%$, Pajak reklame $4 \%$, kemudian tersebar pada jenis pajak lain yang mmemberikan kontribusi ke PAD.

Kabupaten Sumbawa memiliki 11 jenis pajak yang juga sama dengan Kabupaten Lombok Timur, kontribusi pajak 35\% berasal dari pajak penerangan jalan, PBB pedesaan dan kota $16 \%$, Pajak hotel $14 \%$, BPHTB 10\%, Pajak mineral bukan logam dan batuan $10 \%$, pajak restoran $8 \%$, kontribusi untuk jenis pajak yang lainya berkisar dibawah $8 \%$.

Kota Mataram sebagai kota provinsi yang memiliki kegiatan ekonomi yang terpusat di Kota baik dari jasa maupun kegiatan ekonomi lainya, Jenis pajak yang memberikan kontribusi pada PAD adalah 11 jenis, yang memberikan ontribusi terbesar adalah dari pajak penerangan jalan sebesar 27\%, BPHTB 18\%, PBB 17\%, Pajak hotel $16 \%$, pajak restoran $15 \%$, pajak hiburan 25, pajak parker dan reklame hanya masing-masing $1 \%$. Kontribusi dari pajak yang lain kurang dari $1 \%$.

Kota Bima juga memiliki 11 jenis pendapatan dari pajak yang memberikan kontribusi terhadap PAD. Pajak penerangan jalan membeikan kontribusi terbesar 52\%, PBB sebesar 2\%, BPHTB 1\%, diikuti oleh jenis pajak yang lain berada di bawah $1 \%$.

Kabupaten Sumbawa Barat memiliki 10 jenis pajak yang memberikan kontribusi PAD. Kontribusi pajak daerah yang terbesar diberikan oleh Pajak mineral bukan logam dan batuan sebesar 27\%, PBB pedesaan dan kota $5 \%$, Pajak restoran $40 \%$, pajak penerangan jalan $21 \%$, dari jenis pajak yang lain memberikan kontribusi di bawah 1\%. Pajak burung walet tidak ada di dalam penerimaan pajak daerah.

Kabupaten Lombok Utara memiliki 11 sumber penerimaan dari pajak daerah yang memberikan kontribusi kepada PAD. Pajak Hotel memiliki kontribusi 45\%, sedangkan pajak restoran sebesar $24 \%$, BPHTB 8\%, PBB pedesaan dan perkotaan $7 \%$, dan Pajak mineral bukan logam dan batuan $3 \%$, sedangkan untuk jenis pajak yang lain memberikan kontribusi dibawah $1 \%$.

\section{Provinsi NTT}

Kabuapten Alor memiliki 8 jenis pajak yang memberikan kontribusi pada PAD yaitu pajak hotel, pajak restoran, pajak hiburan, pajak reklame, pajak penerangan jalan, pajak mineral bukan logam dan batuan, PBB, BPHTB. Kontribusi PBB dan BPHTB sebesar $25 \%$, dan untuk pajak yang lain berkisar pada 1-23\%.

Kabupaten Belu ada 9 jenis pajak yang memberikan kontribusi terhadap PAD, seperti pada Kabupaten Alor 8 jenis ditambah pajak air dan mineral. Pajak yang terbesar memberikan kontribusi adalah pajak mineral bukan logam dan batuan $37 \%$, pajak penerangan jalan 22\%, Pajak restoran $18 \%$. Dan diikuti oleh jenis pajak yang lain bekisar antara 1-10\%.

Kabupaten Ende sama seperti kabupaten Alor ada 8 jenis pajak daerah yang mememberikan kontribusi terhadap PAD. Kotribusi penerangan jalan memberikan kontribusi sebesar 41\%, Pajak mineral bukan logam dan batuan sebesar $22 \%$. 
Kabupaten Flores Timur memiliki 9 sumber pendapatan yang berasal dari pajak, kontribusi diberikan $42 \%$ dari penerangan jalan, diikuti dari PBB pedesaan dan kota sebesar $22 \%$.

Kabupaten Kupang memiliki 9 sumber pajak daerah, termasuk pada pajak pengambilan bahan galian $\mathrm{C}$. Kontribusi dari pajak mineral bukan logam dan batuan adalah sebesar 47\%, PBB 25\%, pajak penerangan jalan $20 \%$.

Kabupaten Lebata memiliki 7 jenis pajak yang memberikan kontribusi terhadap PAD. Pajak mieral dan bukan logam dan batuan memberikan kontribusi sebesar $33 \%$.

Kabupaten manggarai ada 9 jenis pajak yang memberikan kontribusi terhadap PAD. Namun tidak ada pajak galian golongan C. . Kontribusi 50\% diberikan oleh pajak mineral bukan logam dan batuan. Diikuti oleh pajak penerangan jalan sebesar $15 \%$, dan 12\%berasal dari pajak restoran.

Kabupaten Ngada memiliki 8 jenis pajak yang menjadi sumber pendapatan daerah. Dimana Pajak mineral bukan logam memberikan kontribusi 33\%.

Kabupaten sikka ada 10 jenis pajak yang bisadigali memberikan kontribusi di PAD, adanya pajak air tanah dan pajak parker menjadi penambahan dalam memberikan tambahan pada PAD. Pajak penerangan jalan yang memberikan kontribusi sebesar $31 \%$, dan $12 \%$ berasal dari pajak mineral bukan logam dan batuan, PBB, BPHTB. Begitu pula dengan Kabupaten Sumba Barat Daya memiliki 10 jenis pajak daerah. Kabupaten Sumba Timur, Kabupaten timur tengah selatan, Kabupaten Timur Tengah selatan, Timur tengah Utara, Kabupaten Ngako, Kabupaten Malaka masing-masing memiliki 8 jenis pendapan yang bersumber dari pajak daerah.

Begitu pula dengan Kota Kupang, Kabupaten Rote Ndano, Kabupaten Manggarai barat, Kabupaten manggarai Timur, memiliki 9 jenis sumber pajak.

Berbeda dengan Sumba Tengah yang hanya memiliki 6 jenis Pajak dan Kabupaten Sabu Raijua memiliki 7 jenis sumber pajak daerah.

\section{Rata-Rata Jumlah Realisasi Pajak Kabupaten/Kota di NTB}

Kabupaten/Kota di Provinsi NTB berjumlah 10 yaitu kabupaten Bima, Dompu, Lombok Barat, Lombok tengah, Lombok Timur, Sumbawa, Kota Mataram, Kota Bima, Sumbawa barat, Lombok Utara. Masingmasing Kabupaten/Kota memiliki pariasi jenis pajak yang memberikan kontribusi terhadap PAD. Pariasi rata-rata Kontribusi adalah sekitar 5-10\%. Jenis pajak dari setiap Kabupaten/Kota berkisar antara 811. 
Tabel 1. Rata-rata realisasi Pajak kabuapten/Kota di Provinsi NTB

\begin{tabular}{|l|r|}
\hline \multicolumn{1}{|c|}{ Kabupaten/Kota } & \multicolumn{1}{c|}{ Rata Pajak daerah (RP) } \\
\hline Kab. Bima & $12,750,626,765$ \\
\hline Kab. Dompu & $10,961,436,952$ \\
\hline Kab. Lombok Barat & $102,397,376,617$ \\
\hline Kab. Lombok Tengah & $69,785,785,673$ \\
\hline Kab. Lombok Timur & $61,020,187,603$ \\
\hline Kab. Sumbawa & $28,817,280,872$ \\
\hline Kota Mataram & $144,866,671,600$ \\
\hline Kota Bima & $12,531,828,128$ \\
\hline Kab. Sumbawa Barat & $23,021,082,948$ \\
\hline Kab. Lombok Utara & $92,645,659,869$ \\
\hline
\end{tabular}

Sumber: djkp. Kementrian Keuangan (diolah)

\section{Rata-Rata Jumlah Realisasi Pajak} Kabupaten/Kota di NTT

Perbedaan dari jumlah realisasi setiap Kabupaten/Kota di Provinsi NTT disebabkan oleh pariasi jenis penerimaan pajak yang dipungut. Jenis pajak yang di pungut di Setiap Kabupaten/Kota berpariasi antara 6-10 jenis pajak. Jenis pajak yang memberikan kontribusi yang banyak adalah di pajak mineral bukan logam dan batuan, Pajak galian golongan $\mathrm{C}$, PBB pedesaan dan kota, BPHTB. Kecuali pada Kabupaten Kupang adanya tambahan sumber dari hotel dan restoran. Kabupaten
Kupang memiliki kontribusi ke PAD lebih besar. Ada 21 Kabupaten/kota di Provinsi NTT yang masing-masing memberikan kontribusi yang berbeda terhadap PAD. Dari 11 jenis yang menjadi sumber pajak yang ditetapkan oleh Undang-Undang hanya 6-10 yang terserap dilaksanakan. Seperti diikuti oleh Kabupaten manggarai, Kabupaten Kupang, Kabupaten Alor, Kabupaten Sumba Barat daya, Kabupaten Sumba, Kabupaten Belu, Kabuapten Ende dan kabupaten lainya. Kontribusi Pajak daerah terhadap PAD masih sekitar di bawah $5 \%$.

Tabel 2. Rata-rata realisasi Pajak daerah Kabupaten/Kota di Provinsi NTT tahun 2008-2019

\begin{tabular}{|l|r|}
\hline \multicolumn{1}{|c|}{ Kabupaten/Kota } & \multicolumn{1}{c|}{ Rata -Rata Pajak daerah (RP) } \\
\hline Kab. Alor & $15,513,025,177$ \\
\hline Kab Belu & $12,377,234,072$ \\
\hline Kab. Ende & $11,067,457,626$ \\
\hline Kab. Flores Timur & $7,014,880,395$ \\
\hline Kab. Kupang & $19,713,195,578$ \\
\hline Kab. Manggarai & $18,846,718,341$ \\
\hline
\end{tabular}




\begin{tabular}{|l|r|}
\hline \multicolumn{1}{|c|}{ Kabupaten/Kota } & \multicolumn{1}{c|}{ Rata -Rata Pajak daerah (RP) } \\
\hline Kab. Ngada* & $6,902,392,567$ \\
\hline Kab. Sikka & $15,235,535,867$ \\
\hline Kab. Sumba Barat* & $13,813,508,940$ \\
\hline Kab. Sumba Timur & $11,824,403,188$ \\
\hline Kab. Timor Tengah Selatan & $8,718,779,748$ \\
\hline Kab. Timor Tengah Utara & $7,497,585,016$ \\
\hline Kota Kupang & $98,639,548,268$ \\
\hline Kab. Rote Ndao* & $6,928,685,341$ \\
\hline Kab. Manggarai Barat & $45,584,736,579$ \\
\hline Kab. Nagekeo & $3,861,828,983$ \\
\hline Kab. Sumba Barat Daya & $13,395,658,504$ \\
\hline Kab. Sumba Tengah & $4,925,082,760$ \\
\hline Kab. Manggarai Timur & $10,803,243,281$ \\
\hline Kab. Sabu Raijua & $2,562,123,908$ \\
\hline Kab. Malaka* & $9,695,232,176$ \\
\hline
\end{tabular}

Sumber: djkp.kementrian keuangan (diolah)

Kontribusi Pendapatan Asli Daerah (PAD) terhadap Pendapatan Daerah dalam Anggaran Pendapatan dan Belanja Daerah (APBD) bervariasi, tapi secara rata-rata memang masih rendah. Proporsi PAD baru 24,78 persen dari total pendapatan daerah. Data itu menunjukkan bahwa pemerintah daerah, baik di tingkat provinsi maupun kabupaten/kota masih sangat bergantung pada pemerintah pusat. Grafik dan tabel di atas memperlihatkan, masih banyak pemerintah kabupaten/atau kota yang sumbangan PAD-nya tak sampai 10 persen dari total pendapatan daerah.

Masalah buat pemerintah daerah adalah jenis dan besaran pajak daerah dan retribusi daerah sudah ditentukan pemerintah pusat. Ketentuan ini diatur dalam UU No. 28/2009 tentang Pajak
Daerah dan Retribusi Daerah. Itu sebabnya, pemerintah daerah harus kreatif menciptakan sumber pendapatan baru. Sebaliknya, kabupaten atau kota yang memiliki PAD yang tinggi kebanyakan kota besar yang mengandalkan bisnis dan pariwisata. Salah satu penyumbang terbesar PAD di kabupaten/kota adalah pajak restoran, yang juga dikenal sebagai Pajak Pembangunan 1 (PB-1). Itu sebabnya, Kabupaten Badung (Bali), dan Surabaya, misalnya, punya PAD tinggi.

Seperti pada data di Kabupaten/Kota di NTB sebagian pajak bersumber dari pariwisata dan bisnis serta jasa. Berbeda dengan Kabupaten/Kota di provinsi NTT pajak bersumber dari Bahan mineral bukan logam dan batuan pajak galian golongan $C$. Di Lombok Tengah yang merupakan 
daerah tempat pengembangan pariwisata dan Bisnis yaitu Kawasan Ekonomi Khusus (KEK) Mandalika diupayakan bisa mmemberikan kontribusi dari berbagai sektor yang memberikan pengaruh terhadap pajak dan PAD daerah dan Provinsi. Terkait dengan Pajak terhadap APBD di kedua Provinsi rata-rata hanya memberikan kontribusi 5-10\% . Reformasi pajak diperkenalkan sebagai salah satu dari serangkaian langkah kebijakan dalam kaitanya dengan penghematan pengeluaran terkait dengan penerimaan publik (Gillis, 1985).

\section{KESIMPULAN}

Dana yang bersumber dari pajak di Kabupaten/Kota Privinsi NTB berkisar antara 5-10\% dari terhadap PAD, tapi tidak menutup kemungkinnan juga bahwa ada kabupaten yang masih rendah dengan kontribusi di bawah $5 \%$ terutama bagi daerah kabupaten/kota yang baru terjadi pemekaran. Begitu pula dengan Kabupaten/Kota di Provinsi NTT yang rasio pajak terhadap PAD berkisar antara 1-5\%. Perbedaan dari kedua provinsi diseabbkan oleh pariasi jenis pajak yang dipungut di setiap daerah. Di NTB jenis pajak yang dipungut adalah 8-11 jenis, sedangkan di NTT 6-10 jenis. Potensi di kedua daerah juga berbeda dimana di NTB lebih banyak jenis pajak di bidang pariwisata dan jasa serta bisnis, sedangkan di NTT lebih mengandalakan sumber daya alam di bidang mineral bukan logam dan batuan serta galian golongan $C$. Perlunya pengembangan kawasan bisnis yang mengikutsertakan swasta dalam pengelolaan potensi yang di miliki setiap Kabupaten/Kota seperti di bidang pariwisata, jasa, dan pengelolaan sumber daya alam yang bisa meningkatkan PAD dan mendapatkan manfaat bagi masyarakat di daerah.

\section{DAFTAR PUSTAKA}

Adhamaski. 2015. Menggenjot Kinerja Ekonomi Daerah.

(http://www.coreindonesia.org/view/147/menggenjot-kinerja-ekonomidaerah.html. Diakses pada tanggal 5 September 2021)

Halim, Abdul. 2001. Manajemen Keuangan Daerah. Yogyakarta: Penerbit Bunga Rampai Ismail, Tjip. 2011. Hukum Pajak dan Acara Perpajakan. Universitas Terbuka Ismail, Tjip. 2007. Pajak Daerah Di Indonesia, Edisi kedua. Jakarta: Yellow Printing Suryani. Faisal, Hasan basri. 2016. Analisis Kondisi Keuangan kabupaten/kota di Aceh dan Sumatra Utara. Jurnal Bisnis dan Ekonomi (JBE), Maret2016, Hal.63-7. ISSN: 14123126

Word Bank. 2011. Desentralisasi Fiskal di Indonesia satu dekade setelah desentralisasi (http://www.djpk.kemenkeu.go.id/wpcontent/uploads/2016/01/deskripsi_dan_ analisis_APBD_2011_a.pdf. Diakses pada 7 September 2021) 
Zulkarnain, Z. 2020. Analisis rasio keuangan daerah untuk mengukur kinerja keuangan pemerintah Kabupaten/kota di Jwa Barat. Cakrawala-Repositori IMWI | Volume 3, Nomor 1, April 2020. p-ISSN: 2620-8490; e-ISSN: 2620-8814

Gillis, Malcolm. 1985. Micro and macroeconomics of tax reform: Indonesia. Journal of Development Economics Volume 19, Issue 3, December 1985, Pages 221-254 https://doi.org/10.1016/0304-3878(85)90030-6 